\title{
Memes of Translation Revisited: From Translating Poetry to 'Poeming' Translation
}

\author{
Mounir Jilani Ben Zid \\ Sultan Qaboos University, Sultanate of Oman
}

\begin{abstract}
Despite different approaches, mainstream translation theorists and practitioners have always grappled with some notion of formal cultural and linguistic equivalence to translate literary works. Taking up the question of whether a faithful translation should maintain cultural heterogeneity and linguistic differences, the primary intent of this paper is to destabilize "safe" conceptions associated with literary translation and deconstruct the "comfortable fallacy" of conventional iron-clad rules such as equivalence and faithfulness. More specifically, the paper calls for a move from the mainstream cultural and linguistic discourse in translation studies towards an innovative translation model that goes beyond the limits of language and breaks cultural barriers. On the basis of this approach, the translator is a cultural and linguistic broker able to distinguish between the cultural and linguistic conditions of meaning and meaning itself - the one who 'poems' translation, re-creates or accommodates the ST and prefers beauty to faithfulness. This discussion is substantiated by examples of poems by Omani poets translated from Arabic into English and French by the present author.
\end{abstract}

Index Terms - poetry translation, faithfulness, equivalence, beauty, 'poeming', trans-creation

\section{INTRODUCTION}

No one with an interest in literary translation can fail to notice that the current status of literary translation appears to be one of great confusion and tension, with multiple parties seeking consensus about the types of paradigms and methods to be used. Pessimistic statements on the translatability of poetry in particular are much more common than affirmative ones, as the American poet Robert Frost remarked when he stated that "Poetry is what gets lost in translation" (Schub, 2003, p. 81).

In this regard, opponents of literary translation argue that translations of literary works "[are] meddling with inspiration" (Showerman, 1916, p. 100), that they are "as tasteless as a stewed strawberry" and are, as the French critic Gilles Ménage declared, "like women, either beautiful or faithful, but not both at the same time" (1990, p. 231) .

There are several reasons for such a pessimistic view. One of the reasons for the difficulty—even impossibility—of achieving a faithful or perfect translation of poems is the cultural-social component that the translator has to face, since the meaning, the content, and the form of a poem depend a great deal on the source and target culture. Putting forward a parallel assertion, Walter Benjamin contends that "no poem is intended for the reader, no picture for the beholder, and accordingly no original for a translation" (1992, p. 72).

Another argument against poetry translation is that the translator is likely to find himself under constant pressure owing to the conflict between form and meaning, which often results in a considerable loss of either the meaning or the stylistic qualities of the original. In addition to the cultural, social, and stylistic difficulties the translator may face in translating poetry, there are also pragmatic problems and losses of allusions, images, and references hidden in the author's special choice of words. As Yves Bonnefoy expresses it, the difficulty of translating a poem lies in the retention of "the spiritual statement" or the poem's "secret life" (Older, 1994, p. 29).

Nevertheless, dismissing such a pessimistic posture, yet recognizing the difficulty of the task, this study argues that poetry is what is gained in translation and that it is worth focusing on models of a more positive nature. To this effect, this paper begins with the exploration and development of two prevalent theoretical positions on the translation of poetry. One is a mainstream and conventional approach based on the principle of "equivalence," which strives to "foreignize" and adapt to the original poem in order to meet the cultural expectations of its stylistic forms and which eventually results in a faithful carbon copy of the original source language text. The other translation paradigm is a strategy which, while de-emphasizing the source text, focuses more on the target-reader and recreates a new target language hologram where the author-translator's role is not only to be faithful to the source text but also to "domesticate," reinvent and recreate the target text, and suggest "something beyond its literal sense" (Eco, 2004, p. 7). It is this second paradigm that the present study advocates.

Finally, and in contrast to some critics' argument that poetry loses in translation, the present paper aims to show that, although some of the original aspects of poems cannot be transposed, they can be recreated and re-painted and that "new arrangements may be even more luminous than the original" (Kopp, 1998, p. 162).

\section{TRAnslating PoEtry: PoEms As Faithful WOMEN}


In accordance with the traditional approach, a considerable number of translation theorists and scholars emphasize that poetry translation is complex, not only because a poem is rich in linguistic, cultural, social, and aesthetic value, but also because translators engage in "an intense reaction to linguistic, psychological, anthropological and cultural phenomena (Schulte, 1987, p. 2).

One of the most pivotal principles of the conventional approach to literary translation has been the question of "equivalence," fidelity, or "faithfulness" to the source text. In this respect, a good translation is seen as an attempt to stay as close to the original text as possible in content, language, and rhyme. According to this translation paradigm, the translator offers a literal translation of a given poem and 'foreignizes' the target language text, i.e., sticks to "the text, the whole text, and nothing but the text," keeping the source language values and making them salient in the target language. Accordingly, the target language readers will feel that the translator is 'visible' and they can tell "they are reading a translation" (Munday, 2001, p. 147).

Furthermore, discussing poetry translation from this conventional standpoint, Willis Barnstone asserts that the purpose of literal translation is to transfer the meaning of words as faithfully as possible rather than to "reinvent the formal qualities of the message [or] to 'recreate' dramatically the signifier itself" (1993, p. 229). In this sense, the translation of poems consists in a faithful reproduction, word for word, of the original poem, rendering the meaning of the source text, without adding to or subtracting from it. Hence, the translator is called upon to 'foreignize' and conform to the grammatical and idiomatic conventions of the source text.

\section{A. Application}

This part of the paper is devoted to a discussion of three modern Omani poems composed during the years 1970-1990 and translated into English and French by the present author, treating a range of 'glocal' issues, from personal to universal, such as love, memory, and nature. It starts with a literal translation of the original poems and then shifts to a domestic re-creation of the target language text. The three poems selected for translation into English and French are from the works of three contemporary Omani poets, namely Said Al-Saklawi, Hilal Al-Amri, and Badr Al-Shibani. The three poets reflect on the theme of love and memory, lamenting the loss of a poetic vision and dreaming of a better position in the kingdom of love and beauty.

In my translation of the three poems, I have adhered to the conventional premises and I have tried to remain as close and faithful as possible to the source text in order to give readers an insight into the original poems. Based on this translation strategy, the literal (word-for-word) rendering of the three original poems is faithful to the meaning of the original form, to its content and stylistic features. However, such a translation has given little attention to sound and rhythm and has not been able, in my view, to create an aesthetic effect since some lines in the three poems are too long and lack rhythm and rhyme.

\section{B. Target Texts (English): Translating Poetry}

\section{Confused Tears}

Said Al-Saklawi

In the shades of aspirations, in his childhood's tenderness I slept

For he is my prime of youth and he is aspiration for my heart

I know not where he has gone, I know not where it's going to end

My tears are falling down from my eyes like water, blame not my tears,

I'm weeping for his love

Blame me not my friend, blame me not, blame me not

Where is my life, my love, and my flourishing stars?

Where is my dawn's harp, where is the whispering of breeze?

Where are my flowers, my spring, and my shining sun?

My love went astray, my heart lost its way in the dark seas

Will evening gatherings be back again?

Will my branches get green or will they remain branchless?

Will the sun clothe my morning or will it be dressed in darkness?

Will the star enlighten my nights and will life sing for me again?

\section{Love is Sleeping in Your Eyes}

Hilal Al-Amri

And I can see and love the sea in your eyes

For the waves in your eyes are tales

That tell, preserve history, and count times

Your trembling eyes look like the sea

And your eye-lashes are like waves that travel in the world of dreams

Barren of any destiny

Your glances wash my sadness as a bare wave washes thousands of beaches

The sea has slept in your eyes for so long

And the night has told records of love 
And the waves of love came on a boat

Searching for your eyes to sail on them

Searching for your eye-lashes to protect them

So that love can sleep in your eyes

So that grief is thrown into the deep sea

\section{Your Love is Greater}

Badr Al-Shibani

I can feel your love is getting greater and greater, when the sky is cloudy and rainy

And I write beautiful, beautiful poems to paint your love in every book

And I fill my field with perfumes, with perfumes, for the fields flourish with your perfumes

And I can feel my heart can break all boundaries, if the breeze commiserates and forewarns,

For my heart can see you with an eye that says you are the most beautiful sight

And that you are permissible, permissible wine, and that existence gets drunk whenever it comes to you

And it is from your love that spring remains spring

And it is with your smiles that the morning can shine, can turn into a soft light,

into a pearl.

\section{Target Texts (French): Translating Poetry}

\section{Des Larmes Confuses}

Said Al-Saklawi

A l'ombre de ses ambitions, dans la tendresse de son enfance, j'ai dormi

Car il est ma jeunesse et l'aspiration de mon coeur

Je ne sais pas ōu il est allé, je ne sais pas ōu est-ce que ça va finir

Mes larmes tombent de mes yeux comme de l'eau, il ne faut pas m'en vouloir,

Je pleurs son amour

Ne m'en veux pas mon ami, ne m'en veux pas mon ami,

Où sont ma vie, mon amour, et mes étoiles florissantes?

Où est l'aube de ma harpe, ou est le murmure de la brise?

Où sont mes fleurs, mon printemps et mon soleil rayonnant?

Mon amour s'est perdu, mon coeur a perdu son chemin dans les mers obscures

Est-ce que les soirées reviendront de nouveau?

Est-ce que mes branches seront coloriées de vert ou seront sans feuilles?

Est-ce que mes matins seront vêtus de soleil ou vont plonger dans le noir?

Est-ce que les étoiles vont éclairer mes nuits et la vie chantera pour moi encore une fois?

\section{$L$ 'amour Dort dans tes Yeux}

\section{Hilal Al-Amri}

Je peux voir et aimer la mer dans tes yeux

Car les vagues dans tes yeux sont des histoires

Qui racontent, protègent l'histoire et comptent le temps

Tes yeux troublants ressemblent á la mer

Et tes cils ressemblent á des vagues qui voyagent dans le monde des rêves

Sans destin

Tes clins d'oeuil nettoient ma tristesse comme une vague nue nettoie les plages

La mer a longtemps dormi dans tes yeux

Et la nuit a pu préserver des histoires d'amour

Et les vagues d'amour ont navigué

Chercher tes yeux pour y voyager

Chercher tes cils pour les protéger

Afin que l'amour puisse dormir dans tes yeux

Afin que la tristesse soit jetée dans des mers profondes.

\section{Ton Amour est Plus Grand}

\section{Badr Al-Shibani}

Je peux sentir que ton amour devient de plus en plus grand quand le ciel devient nuageux et pluvieux

Et j'écris de beaux poèmes, de beaux poèmes afin de peindre ton amour dans tous les livres

Et je rempli mes champs de parfums, de parfums, car les champs prospèrent avec ton parfum

Et je sens que mon coeur peut briser tous les obstacles, quand la brise compatit et m'avertit

Car mon coeur te voit avec un oeil qui dit que tu es la plus belle

Et que tu es du vin, oui, du vin bénit, et que l'existence devient vre quand elle te rencontre

Et que c'est avec ton amour que le printemps demeure printemps

Et qu'avec tes sourires que les matins brillent, qu'ils deviennent une lumiere douce, une perle.

(My translation) 


\section{III. 'POEMING' Translation: From FaithFul Women to CREATIVE INFIDELS}

Since the translation of the three Omani poems is intended mainly for a readership that can neither read nor appreciate them in their original language (i.e., Arabic), it logically follows that the translation paradigm chosen in this paper must be first and foremost conditioned by the needs of the receptor of the target language. Hence, the future translation paradigm adopted in this paper steps beyond conventional principles and procedures and is more than a mere literal translation involving a great deal of recreation and interpretation. According to this approach, the translator's special role is by no means a passive and mechanical one, but rather that of an artist, a re-creator, and an actor.

Several scholars share this view and consider literary translation to be a creative process. Gui, for instance, believes that "translation is not merely a transformation of an original text into a literal equivalent, but must successfully convey the overall meaning of the original" (1995, p. 135).

In a similar vein, Jackson declares that literary translation is not imitation or a carbon copy of the original, but rather a counterpart or equivalent for expressions used in the source language. In his article entitled "From Translation to Imitation," Jackson argues much the same point. He holds that a translator must consider that "what he writes is similar, but not the very same, and the similarity, moreover, should not be like that of a painting or statue to the person represented, but rather like that of a son to a father, [...] as the bees make honey, not keeping the flowers but turning them into a sweetness of our own, blending many different flavors into one, which shall be unlike them all, and better" (Jackson, 2003, p, 15).

Similarly, Walter Benjamin argues against literal translation, which is a faithfulness or fidelity in the translation of an artistic work. In The Task of the Translator, he emphasizes that it is important to recreate the mode of significance of the source text and that "real translation is transparent, it does not cover the original, does not block its light, but allows the pure language to shine upon the original" (1992, p. 123).

Others, like Lambert, also maintain that literary translation is literary interpretation and that it is "the fruit of a substantial creative effort by the translator, who is the key agent in the subjective activity and social practice of translation" (1988, p. 133). This meshes with Vermeer's Skopos translation theory, which also favors the principle of openness, i.e., an open relationship between the source text and the translated one (1989). Vermeer assumes that the communicative value of the source text is more important than faithfulness to the source text, and that the translator of a poem should therefore be allowed a great deal of freedom as long as he adheres to the essential meaning of the original poem.

In view of the future translation paradigm adopted by the present study, more emphasis is placed on the principle of re-creation, interpretation, and domestication of the source text in my translation of the three Omani poems into English and French. My goal as a translator here has been to reproduce a text that is a translation of the original and is, at the same time, a poem in its own right within the target language. In other words, I was influenced by my personal tastes and preferences in addition to adhering to formal translation criteria when creating a counterpart for the original poems.

It is my view that, despite some sort of stylistic and semantic loss in translating the three Omani poems, all these renderings have succeeded to some extent in capturing the original style, images, and wording. All these variations, moreover, have compensated for the loss of rhythm and rhyme, have introduced an equivalent for the consonant sounds, and have added structural devices such as parallelism in order to reproduce an equivalent aesthetic effect.

\section{A. Target Texts (English): 'Poeming' Translation}

\section{Tears at a Loss}

Said Al-Saklawi

Under the shade of ambition, in his childhood's tenderness I slept

For he was my youthful prime and model for my heart

I know not where he's gone, I know not where it will end

My tears flow down like water

Blame not my tears, I'm weeping for his love

Blame me not, my friend, blame me not

Where my life, my love, my flourishing stars?

Where my dawn's harp and the whispering breeze?

Where my flowers, my spring, my shining sun?

My love strayed far, my heart quite lost in the darkest seas

Will the gatherings of evening come back again?

Will my branches grow green or stay without shoots?

Will the sun clothe my morning or dress it in dark?

Will the stars light up my nights and life sing for me once more?

\section{Love Can Sleep in Your Eyes}

Hilal Al-Amri

And I can see and love the sea in your eyes

For the waves in your eyes are tales

That tell, keep history, and count times 
Your trembling eyes look like the sea

Your eye-lashes are waves that traverse the world of dreams

Barren of destiny

Your glances wash my sadness as a bare wave washes beaches

The sea has slept in your eyes for so long

And the night holds records of love

And the waves of love came on a boat

Searching for your eyes to sail on them

Searching for your eye-lashes to protect them

So that love can sleep in your eyes

So that grief can be thrown into the depths of the sea.

\section{Shall I Describe Thy Love?}

Badr Bin Ali Al-Shibani

I can feel your love is growing always, whenever the sky is cloudy and rainy

And I write beautiful poems to paint it in my books

And I fill my field with perfumes, yes, with perfumes, for the fields flourish with your fragrance

And I feel my heart break the bounds when the breeze commiserates and forewarns,

For my heart sees you with an eye that says you're the loveliest

That you are permissible, yes, permissible wine, and that life gets drunk whenever it meets you

And it's with your love that spring remains spring

And it's with your smiles that morning can shine, can become a soft light,

Can become a pearl.

B. Target Texts (French): 'Poeming' Translation

\section{Des Larmes à Mi-Chemin}

Said Al-Saklawi

Je m'endormais à l'ombre, dans la tendresse de son enfance

Car il est pour moi la jeunesse et tout ce que le coeur désire

Je ne sais où il a disparu, je ne sais où il va en finir

Mes larmes coulèrent comme des gouttes d'eau, ne m'en veux pas,

Je pleurs l'amertume de son amour

Ne m'en veux pas, mon cher, ne m'en veux pas

Où sont partis mon amour et mes étoiles rayonnantes?

Où sont l'aube de ma harpe et le bruissement de la brise?

Où sont mes fleurs, mon printemps et ma jeunesse?

Mon amour, mon coeur ont perdu le chemin dans les mers profondes

Les soirées, les retrouvailles, reviennent-elles un jour?

Mes branches, seront-elles de nouveau vêtues de joie ou ne verront-elles plus le jour?

Mes jours, seront-ils vêtus de soleil ou plongeront-ils dans le noir?

Mes nuits, seront-elles éclairées d'étoiles et la vie chantera-elle pour moi de nouveau?

L'Amour S'en Dort Dans Tes Yeux

Hilal Al-Amri

Je perçois et j'adore la mer à travers tes yeux

Car les vagues deviennent des contes dans tes yeux

Des fées qui racontent l'histoire du temps

Tes yeux frémissants ressemblent à la mer

Tes cils sont des vagues qui traversent le monde des rêves

Dénudés de toutes destinations

Et tes regards me purifient de mon chagrin comme les vagues vierges nettoient la plage

La mer a longtemps rêvé dans le royaume de tes yeux

Et la nuit a longtemps raconté des fées d'amour

Et les vagues d'amour ont pris la mer

A la recherche de tes yeux pour y voyager

A la recherche de tes cils pour les protéger

Afin que l'amour puisse dormir dans tes yeux

Afin que le chagrin se dissolve dans les mers les plus profondes.

\section{Dois-je Décrire ton Amour?}

Badr Al-Shibani

A chaque fois que le ciel est nuageux et pluvieux, je sens que ton amour devient plus puissant Ainsi, je compose de beaux poèmes pour peindre ton amour dans toutes les oeuvres d'art

Et je couvre mes champs de parfum car les champs ne se parfument que de ton parfum 
Et à chaque fois que la brise, d'un air compatissant, me fait signe, je sens que mon coeur se débarrasse de tous les obstacles

Car mon coeur te voit d'un oeil qui déclare que tu es la plus ravissante

Et que tu es du vin, oui, du vin bénit, et que la vie s'enivre en te rendant visite

Et que c'est seulement grâce à ton amour que le printemps garde son printemps

Et que c'est seulement grâce à tes sourires que le soleil rayonne, et se transforme en une lumière douce, en une perle.

\section{CONCLUSION}

The present study has attempted to disclose two prevalent approaches to the translation of three Omani poems, with a special emphasis on a paradigm that advances the claim that language and stylistic features are not everything in a poem, that a poem should focus more on aesthetic effects and has to be appreciated in the first place.

Touching upon dominant translation theories, the study has presented what I consider a more efficient translation strategy, which discourages the tendency towards over-faithfulness, equivalence, and fidelity to the original poem and moves beyond the words set on the page, recreates the poem's aesthetic aspects, and domesticates the source language text by changing the source language values and making them readable for the target language audience.

Yet, giving myself much freedom and license to naturalize the three Omani poems does not mean that the authors and source texts have been ignored in the translation process, nor does it insinuate that a poem is open to endless renderings.

This study has also argued against the belief that "the clumsiest literal translation is a thousand times more useful than the prettiest paraphrase" (Nabokov, 1999, p. 12). Also, an attempt has been made to show that, in case of discrepancy between the meaning of a poem and the demands of its readers, a legitimate interpretation is needed and more emphasis should be put on the tenet of 'poeming' and re-creation. In brief, this study has striven to demonstrate that no translation of a poem is ever "the same as" or "equivalent to" the original poem itself. As James Holmes puts it:

'Equivalence', like sameness, is asking too much ... What the translator strives for is ... not over-all sameness or equivalence... Rather it consists in finding what I should prefer to call 'counterparts' or 'matchings' ... fulfilling functions in the language of the translation and the culture of its reader (Holmes, 2005).

ApPendix. A Source TeXts: ArabiC

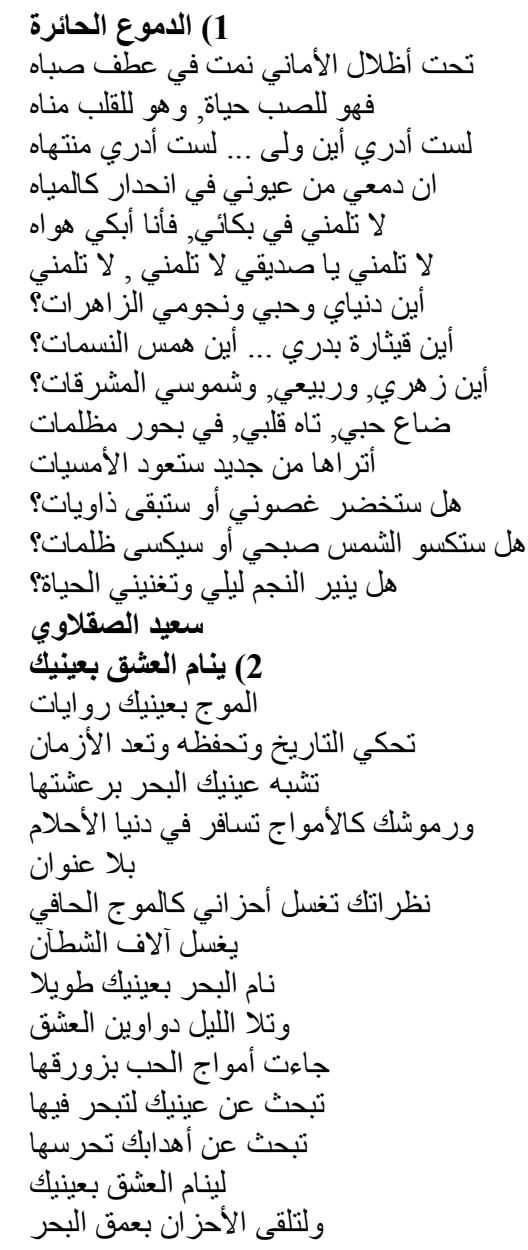



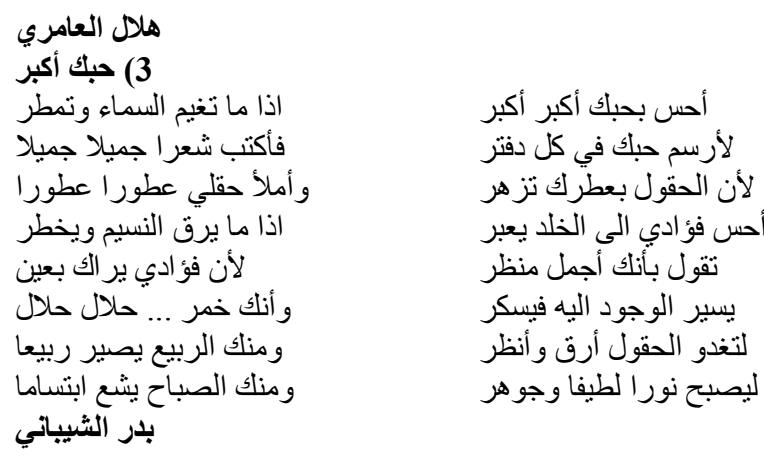

\section{REFERENCES}

[1] Barnstone, W. (1993). The poetics of translation: History, theory, practice. New Haven: Yale University Press.

[2] Benjamin, W. (1992). The task of the translator. In H. Zohn (ed.), Illuminations translated. London. Fontana Press, 70-82.

[3] Eco, U. (2004). Experiences in translation. Toronto: University of Toronto Press.

[4] Gui, G. (1995). Das Wesen des Ubersetzens ist Kreativ. Babel 41.3, 129-139.

[5] Holmes, J.S. (2005). Translated! : Papers on literary translation and translation studies. Netherlands: Editions Rodopi B.V.

[6] Jackson, R. (2003). From translation to imitation. Retrieved from URL (accessed May 5, 2010).

[7] Kopp, M. (1998). Poetry in Translation. Name of Website. Retrieved from URL (accessed February 22, 2010).

[8] Lambert, J. (1988). Literary translation. In M. Baker (ed.), Routledge Encyclopedia of Translation Studies. London: Routledge, 130-134.

[9] Ménage, G. (1990). Elles me rappellent une femme que j'ai beaucoup aimé à Tours, et qui était belle mais infidèle. In A. H. Albir (ed.), La notion de fidélité en traduction. Paris: Didier Érudition.

[10] Munday, J. (2001). Introducing translation studies: Theories and applications. London: Routledge.

[11] Nabokov, V. (1999). Problems of translation: Onegin in English. In L. Venuti (ed.), Translation studies reader. London: Routledge, 71-83.

[12] Older, J. (1994). Poeming a Translation. Poets and Writers Magazine. July/August, 27-31.

[13] Showerman, G. (1916). The way of the translator. Unpopular Review 5, 84-100.

[14] Schub, M.B. (2003). That which gets lost in translation. The Middle East Quarterly X.4, 81-85.

[15] Schulte, R. (1987) Translation theory: A challenge for the future. Translation Review 23, 1-2.

[16] Vermeer, H.J. (1989). Skopos and commission in translation action. In A. Chesterman (ed.), Readings in Translation Theory. Helsinki: Oy Finn Lecturn Ab.

Mounir Jilani Ben Zid received his PhD in British Literature from the Sorbonne University in Paris (France). He started his career as lecturer at the University of Tunis and joined Sultan Qaboos University (Oman) as Assistant Professor in 2006. His research interests include literary translation, stylistics, comparative literature and language education. Mounir is editorial board member of Advances in English Language and Literature journal and the International Journal of English Language Teaching. 